\title{
POPULATION AGEING AND POLAND'S INTERNATIONAL INVESTMENT POSITION
}

\section{Abstract}

The aim of this paper is to try to evaluate the impact of population ageing on Poland's international investment position in the next five decades. To that end, a literature review was carried out along with a comparative analysis of measures of population ageing in Poland and other countries using logical deduction. The results of the study show that the expected intensive progress of population ageing in the 20202065 period will contribute to an increased demand for foreign capital, an increasingly negative international net investment position as well as unfavourable changes in the structure of foreign liabilities. The influx of foreign capital caused by population ageing might not translate into the expected maintenance of / increase in the rate of economic growth, while the substantial negative net international investment position may become a barrier to development in subsequent periods.

Keywords: population ageing, international capital flows, international investment position, Poland.

JEL Classification: F21, F43, J11.

\section{Introduction}

The process of population ageing is of a universal and asymmetric nature. It concerns all countries and regions, but the degree of its progress and its pace differ across countries and regions of the world. This diversification is recognised in the subject literature as a significant factor determining

Renata Knap, University of Szczecin, Institute of Economics and Finance, Department of Economics, Mickiewicza 64, 71-101 Szczecin, Poland, e-mail: Renata.Knap@usz.edu.pl, ORCID: https:// orcid.org/0000-0002-0433-1603.

This is an open access article distributed under the terms of the Creative Commons Attribution-NonCommercial-NoDerivatives 4.0 License (CC BY-NC-ND 4.0); https://creativecommons.org/ licenses/by-nc-nd/4.0/ 
the scale and direction of international capital flows and thereby changes in countries' balance of foreign assets and liabilities, i.e. their international investment position.

All the available forecasts of the demographic changes in Poland indicate that over the next five decades the pace of ageing of the Polish population will accelerate significantly. The economic results of the predicted progress of population ageing in the coming decades have been the focus of multiple analyses and discussions presented in the Polish literature on the subject. However, researchers have concentrated on internal determinants, frequently in isolation from the international aspects of the demographic changes caused by the openness of Polish economy and globalization.

The aim of this paper is to try to evaluate the impact of population ageing on Poland's international investment position in the next five decades.

To that end, a literature review was carried out, which allowed the directions of the impact of population ageing on Poland's international investment position in theoretical terms and in empirical studies to be identified. The progress and pace of Poland's population ageing compared to other countries were defined through a comparative analysis of secondary data, such as life expectancy, population growth rate, age ratio, age index, median age, population age structure, and demographic dependency ratio. The results obtained in the analyses of demographic trends in Poland in relation to the demographic changes in other countries were used to define, using logical deduction, the directions in which population ageing impacts on Poland's international investment position.

Statistical material was obtained from the databases of the UN, the World Bank, the National Bank of Poland, and the Central Statistical Office. The research concerns the 1950-2065 period. Therefore, it encompasses an analysis of the actual development of the studied phenomena in the years 1950-2015 as well as a forecast of their development up to 2065.

\section{The Theoretical Concept of Population Ageing as a Determinant of the International Investment Position}

The international investment position (IIP) is a statistical statement at a given moment in time of foreign financial assets held by residents (receivables from non-residents and monetary gold) as well as of foreign financial liabilities possessed by residents (residents' liabilities to non-residents). The difference between the value of financial foreign assets 
and liabilities constitutes the net international investment position (NIIP) (IMF 2009, p. 119).

The IIP reflects an accumulated value of capital flows (financial transactions registered in the balance of payments) made between a given country and the other countries of the world, adjusted for the changes of the value of foreign assets and liabilities not resulting from the conducted transactions (the ones unregistered in the balance of payments). The changes in the balance of foreign receivables and liabilities are thus a result of the influence of two factors: financial transactions (capital flows) between national and foreign entities as well as other changes (not resulting from the transactions) occurring in a given reporting period (IMF 2009, p. 120). Transactions and other changes may therefore be recognized as two separate channels through which population ageing impacts on the IIP (cf. Figure 1).
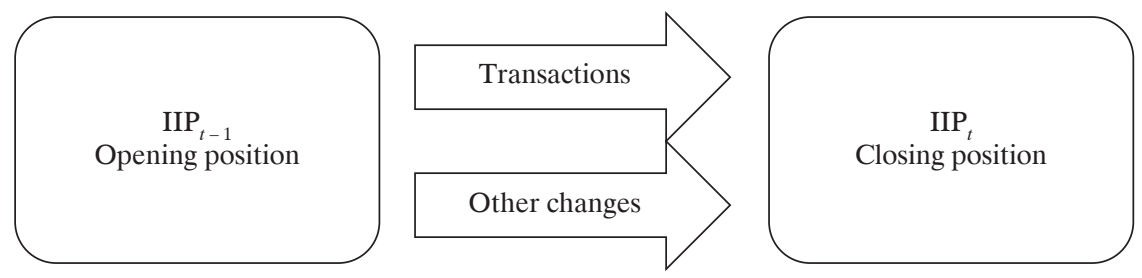

Fig. 1. IIP Change Factors in $t$ Reporting Period

Source: author's own elaboration based on IMF data (2009).

In the subject literature changes in international capital flows (the transactions channel) caused by population ageing processes are recognized as the basic channel in which population ageing affects the IIP. This occurs through changes in national savings and investments (Figure 1).

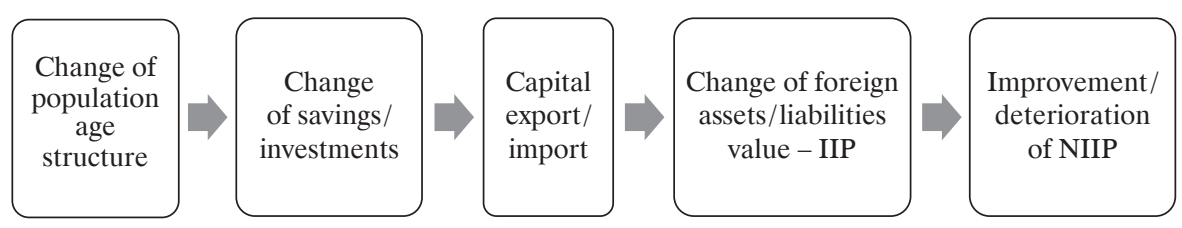

Fig. 2. The Process of Population Ageing Transmission on the IIP - "Transaction" Channel

Source: author's own elaboration. 
The theoretical basis of the research presented in the literature concerning the impact of population ageing on international capital flows and on the IIP originate from a life cycle hypothesis formulated by F. Modigliani, R. Brumberg and A. K. Ando (Bárány, Coeurdacier \& Guibaud 2016, Gudmundsson \& Zoega 2014, Bryant 2006, Börsch-Supan 2004, Higgins 1998). In accordance with that hypothesis, individuals strive to maintain their consumption level at a relatively constant level throughout their entire lifetime. Since income level changes over a life cycle (it increases during the entire period of professional activity until retirement), consumers use the mechanism of borrowing and saving in order to even out the consumption level. Young people typically obtain lower income than their desired consumption level and hence do not save but instead contract loans. Middle-aged people obtain higher income, repay the loans, and accumulate savings in order to maintain the achieved consumption level during their retirement period, which is characterized by a decrease in income. Elderly people at post-working age finance consumption from the life savings they have accumulated. Hence, the hypothesis of a life cycle assumes negative (or very small) savings at a young age, positive savings in middle age, and negative saving in old age (Ando \& Modigliani 1963, Modigliani \& Brumberg 1954).

The hypothesis of a life cycle is also adopted to explain the impact of population ageing on investment needs (Lane \& Milesi-Ferretti 2001). In line with this approach, young populations feature the greatest demand for investment (job creation, satisfaction of educational and housing needs, etc.). In older populations with a substantial percentage of individuals of post-working age, the demand for investment capital drops (a decrease in the supply of labour, shifts in the demand structure from more capital-intensive goods to less capital-intensive ones, etc.).

Therefore, changes in the age structure of a society determine the amount of savings and investments aggregated in the economy ${ }^{1}$. Depending on how advanced the ageing process is, a country shows either a deficit or a surplus of savings in relation to its current investment needs. In countries that are at an early stage of demographic change, with a relatively large percentage of young people, a deficit of national savings is observed and those countries are usually net capital importers from countries with older populations (they record an increase in foreign liabilities and a deterioration of/

\footnotetext{
${ }^{1}$ Research shows that this regularity relates not only to household savings, but also to corporate and public ones (Chawla 2007, pp. 119-123).
} 
a negative NIIP). Countries in which the population ageing process is more advanced, and in which the share of prime savers is on the rise, demonstrate a growth of savings in relation to investment needs. Those countries export capital to younger economies (they record an increase in foreign assets and an improvement of / a positive NIIP). In demographically old countries with a relatively large percentage of the population at post-working age, the scale of the decline in the level of savings is typically greater than that of investment demand. Furthermore, the demand for foreign capital grows (there is an increase in foreign liabilities and a deterioration of / a negative NIIP) (World Bank 2016).

The presented theoretical interpretations of the influence exerted by the process of population ageing on international capital flows and on the IIP have been confirmed in numerous empirical studies (Bárány, Coeurdacier \& Guibaud 2016, Gudmundsson \& Zoega 2014, Bryant 2006, Domeij \& Floden 2006, Chinn \& Prasad 2003, Lührmann 2003, Börsch-Supan, Ludwig \& Winter 2001, Attanasio \& Violante 2000, Higgins 1998).

The development of empirical studies also revealed instances of irregularities between the theory and the actual impact of ageing on the IIP. Those discrepancies served as the basis for identifying the factors that may modify the influence of demography on international capital flows and the IIP. They include the degree of openness (liberalisation) of capital markets and the differences in the level of financial market development and its safety across countries (Mérette \& Georges 2009, Brooks 2003). Moreover, as was demonstrated in the research, saving patterns may in fact differ from country to country and may diverge from the theoretical assumptions of the life cycle hypothesis. On the basis of life cycle models ${ }^{2}$, the differences are attributed to the special conditions in individual countries, such as social security level (in particular, pension system security), cultural conditions or level of affluence (Graff, Tang, \& Zhang 2012, Dekle 2004, Börsch-Supan 1992).

The second channel through which population ageing impacts on the IIP involves other changes in the value of foreign assets and liabilities not caused by transactions (Figure 1). This occurs through changes, triggered by ageing, in the determinants of foreign exchange rate and in the prices of foreign assets/liabilities and their quantitative changes (Figure 3).

Depending on the course of changes caused by ageing in foreign exchange rates and in the prices of financial assets and their other quantitative changes,

${ }^{2}$ Those divergences became the basis for developing an alternative to the life cycle hypothesis a behavioural life cycle hypothesis. For more on this subject, see Bańbuła (2006). 
this channel may deepen or offset the negative impact of transactions on the IIP. The mechanisms of population ageing affecting the IIP through the "other changes" channel are relatively poorly recognised both in theory and in empirical studies, which produce ambiguous results (Hassan, Salim \& Bloch 2011, p. 724; Hassan, Salim \& Bloch 2015, pp. 3-4; Lv 2018, p. 303; Gelinas 2018). To a significant degree, this results from the issue's high degree of complexity and from the lack of availability of sufficiently detailed statistical data.

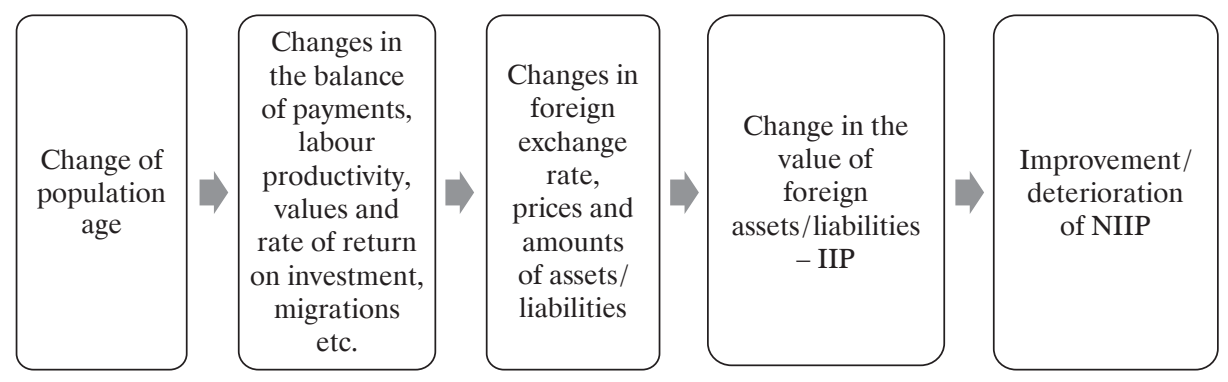

Fig. 3. Process of Population Ageing Transmission on the IIP - "Other Changes" Channel

Source: author's own elaboration.

For this reason, the impact of population ageing through the "other changes" channel is not taken into account in the remainder of this paper. The analysis is limited to the influence exerted by that phenomenon on Poland's IIP via the "transactions" channel.

\section{The Process of Population Ageing in Poland}

According to the concept of demographic transition ${ }^{3}$ and global trends, the socio-economic development of Poland in the post-war period was accompanied by the weakening of demographic dynamics and a rise in average life expectancy. The UN forecasts for Poland for the next fifty years reveal a further increase in life expectancy and a continued decrease in birth rates. In the 2020-2065 period, expected lifespan will be much higher than the global average and will be closer to the average for developed countries. Birth rates, in turn, in contrast to the global average, will be showing negative values. Thus, natural population increase will become a natural

I $\quad{ }^{3}$ For more on the concept of a demographic transition, see Okólski and Fihel (2012). 
population drop, the scale of which will be significantly higher than that observed in developed countries (Table 1).

Table 1. Birth Rates and Life Expectancy in Poland Compared to Economic Regions and to Global Data in the 1950-2065 Period

\begin{tabular}{c|c|c|c|c|c|c|c|c}
\hline \multirow{2}{*}{ Years } & \multicolumn{4}{|c|}{ Birth rate (\%o) } & \multicolumn{4}{c}{ Life expectancy (years) } \\
\cline { 2 - 9 } & Poland & $\begin{array}{c}\text { deve- } \\
\text { loped }\end{array}$ & $\begin{array}{c}\text { develop- } \\
\text { ing }\end{array}$ & world & Poland & $\begin{array}{c}\text { deve- } \\
\text { loped }\end{array}$ & $\begin{array}{c}\text { develop- } \\
\text { ing }\end{array}$ & world \\
\hline $1950-1955$ & 18.8 & 11.8 & 20.6 & 17.8 & 61.4 & 64.8 & 41.7 & 47.0 \\
\hline $1960-1965$ & 11.9 & 10.1 & 23.0 & 19.2 & 68.3 & 69.5 & 46.2 & 51.2 \\
\hline $1970-1975$ & 9.0 & 6.5 & 24.1 & 19.5 & 70.3 & 71.1 & 54.9 & 58.1 \\
\hline $1980-1985$ & 9.4 & 4.7 & 21.8 & 17.8 & 70.7 & 72.9 & 59.5 & 62.1 \\
\hline $1990-1995$ & 3.4 & 2.3 & 18.6 & 15.2 & 71.2 & 74.2 & 62.5 & 64.6 \\
\hline $2000-2005$ & 0.0 & 0.7 & 15.3 & 12.5 & 74.6 & 75.6 & 65.5 & 67.2 \\
\hline $2010-2015$ & 0.1 & 1.1 & 14,1 & 11.9 & 77.0 & 78.4 & 69.1 & 70.8 \\
\hline $2020-2025^{\mathrm{a}}$ & -2.8 & 0.1 & 11.6 & 9.8 & 78.7 & 80.1 & 71.4 & 72.9 \\
\hline $2030-2035^{\mathrm{a}}$ & -4.8 & -1.0 & 9.4 & 7.8 & 80.3 & 81.7 & 73.3 & 74.7 \\
\hline $2040-2045^{\mathrm{a}}$ & -6.2 & -1.7 & 7.6 & 6.3 & 82.0 & 83.2 & 75.0 & 76.2 \\
\hline $2050-2055^{\mathrm{a}}$ & -7.2 & -2.0 & 5.9 & 4.8 & 83.4 & 84.5 & 76.5 & 77.6 \\
\hline $2060-2065^{\mathrm{a}}$ & -8.5 & -2.0 & 4.4 & 3.63 & 84.6 & 85.8 & 77.8 & 78.9 \\
\hline
\end{tabular}

${ }^{a}$ Forecast.

Source: author's own elaboration based on United Nations (2018).

Poland's population is further affected by migration flows, the balance of which in the 1950s was negative (Figure 4). Although the forecasts indicate an improvement, it will still remain negative, while developed countries as a group will maintain a high, positive migration balance. According to the forecast, in 2065 Poland will have the greatest negative foreign migration balance in all of Europe, "surpassing" in that regard the net migration of countries such as Romania, Albania or Serbia (UN 2018). The negative balance of migration will contribute not only to Poland's depopulation, but also to changes in the population age structure. Young people (aged well below 65, which include - amongst women - women of reproductive age) predominate among emigrants from Poland (GUS 2018).

As a result of a decrease in birth rates, a rise in life expectancy, and a negative migration balance, Poland's population has been ageing. In the 1950-2015 period, the value of the demographic age ratio, i.e. the percentage of individuals aged 65 and older $(65+)$ in the population in total grew 
three-fold - from 5.2\% in 1950 to $15.6 \%$ in 2015 (Table 2). In line with the UN classification ${ }^{4}$, Poland's population changed from a mature population (in which the percentage of people aged $65+$ does not exceed $7 \%$ ) into an old population (in which the percentage of people aged $65+$ is higher than $7 \%$ ).

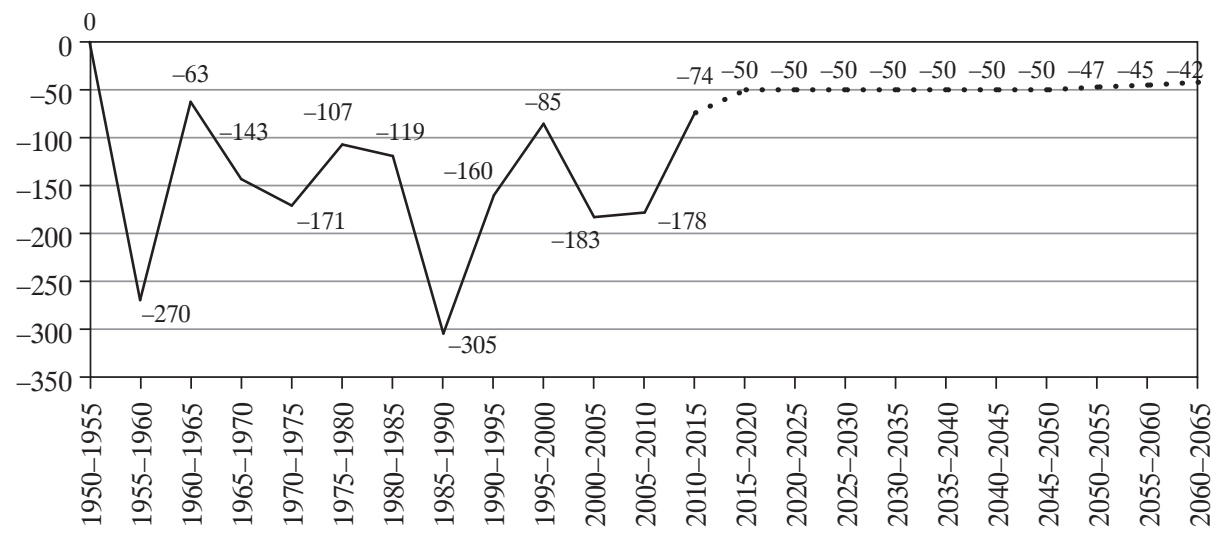

Fig. 4. Poland's Net Population Migration in 1950-2015 and a Forecast for 2020-2065 (1000S of People)

Source: author's own elaboration based on GUS (2018).

In the 1950-2015 period, the value of the age index, which reflects the relation between the generation of grandparents and the generation of grandchildren (the number of persons aged 65+ relative to the number of persons aged 0-14), rose nearly six-fold - from $17.8 \%$ in 1950 to $104.9 \%$ in 2015. According to the forecast, in 2050 this index will be as high as $299.2 \%$, which means that there will be 300 grandparents per 100 grandchildren (Table 2).

The accelerated ageing of Poland's population is further demonstrated by the change in the population age median, which rose from 25.8 in 1950 to 39.7 in 2015 (Table 2). Already in the 1980's its value exceeded the threshold of 30 years of age, after which a population is considered to be demographically old.

${ }^{4}$ According to the UN classification: young population - the percentage of people $65+$ is lower than $4 \%$; mature population - the percentage of people $65+$ is between $4 \%$ and $7 \%$; old population - the percentage of people $65+$ is higher than $7 \%$; very old population - the percentage of people $65+$ is higher than $20 \%$ (United Nations 2005). 
The ageing of Poland's population is also evident in the changes in the demographic dependency ratio, which is the relationship between the number of people in age groups established according to economic criteria (in this paper it was assumed that up to 19 years of age is pre-working age, between 20 and 64 is working age, and $65+$ is post-working stage). In the 1950-2015 period, the relation between the number of people of post-working age $(65+)$ to the number of people of working age (20-64) grew in Poland from $9.4 \%$ to $24.3 \%$ (Table 2).

Table 2. Measures of Population Ageing in Poland, 1950-2065

\begin{tabular}{|c|c|c|c|c|c|c|}
\hline \multirow[b]{2}{*}{ Years } & \multirow[b]{2}{*}{$\begin{array}{c}\text { Age } \\
\text { median } \\
\text { (years) }\end{array}$} & \multirow[b]{2}{*}{$\begin{array}{l}\text { Age } \\
\text { ratio } \\
(\%)\end{array}$} & \multirow[b]{2}{*}{$\begin{array}{l}\text { Age } \\
\text { index } \\
(\%)\end{array}$} & \multicolumn{3}{|c|}{ Demographic dependency ratio $(\%)$} \\
\hline & & & & $\begin{array}{c}\text { old age } \\
(65+/ 20-64)\end{array}$ & $\begin{array}{c}\text { young age } \\
(0-19 / \\
20-64)\end{array}$ & $\begin{array}{c}\text { total } \\
(0-19 \text { and } \\
65+/ 20-64)\end{array}$ \\
\hline 1950 & 25.8 & 5.2 & 17.8 & 9.4 & 70.2 & 79.6 \\
\hline 1960 & 26.5 & 5.7 & 17.0 & 10.5 & 74.1 & 84.7 \\
\hline 1970 & 28.1 & 8.2 & 30.1 & 15.2 & 69.9 & 85.1 \\
\hline 1980 & 29.5 & 10.2 & 42.5 & 17.6 & 54.9 & 72.5 \\
\hline 1990 & 32.2 & 10.0 & 39.6 & 17.3 & 56.8 & 74.1 \\
\hline 2000 & 35.0 & 12.0 & 61.5 & 20.1 & 47.3 & 67.5 \\
\hline 2015 & 39.7 & 15.6 & 104.9 & 24.3 & 31.4 & 55.7 \\
\hline $2030^{\mathrm{a}}$ & 46.3 & 23.2 & 181.6 & 39.3 & 30.4 & 69.7 \\
\hline $2050^{\mathrm{a}}$ & 52.2 & 31.6 & 219.6 & 60.8 & 31.4 & 92.2 \\
\hline $2060^{\mathrm{a}}$ & 52.8 & 35.6 & 259.2 & 74.3 & 34.5 & 108.8 \\
\hline $2065^{a}$ & 53.3 & 35.8 & 293.8 & 74.9 & 34.4 & 109.2 \\
\hline
\end{tabular}

${ }^{\text {a }}$ Forecast.

Source: author's own elaboration based on United Nations (2018).

It is forecast that in the next five decades Poland's population will be undergoing significant advancement of the ageing process. In accordance with UN demographic forecasts, in 2065 the age ratio will rise to $35.8 \%$, the population age median will increase to 53.3 , the dependency ratio of elderly people will be as high as 74.9 , and the total demographic dependency ratio will be over 109\% (Table 2).

A comparison of the measures of Poland's population ageing with the global average and the averages for economic regions shows that in the 1950-2015 period Poland had a relatively young population - the values of the measures in that period were below the average recorded for the group 
of developed countries. According to the theory of demographic transition, the progress of ageing in Poland was still higher than the average for less developed countries, which on account of their dominant share in the world population determined the global average values of age ratios (cf. Figure 5).

In line with UN forecasts, in the five decades between 2015 and 2065 the relative demographic position of Poland will undergo radical change. It is predicted that from around 2020 the process of population ageing in Poland will accelerate strongly, which will result in Poland's population showing significantly higher values as regards ageing measures not only in relation to the group of less developed countries and to the world average, but also in relation to the average for highly developed countries (cf. Figure 5).

a) Age median

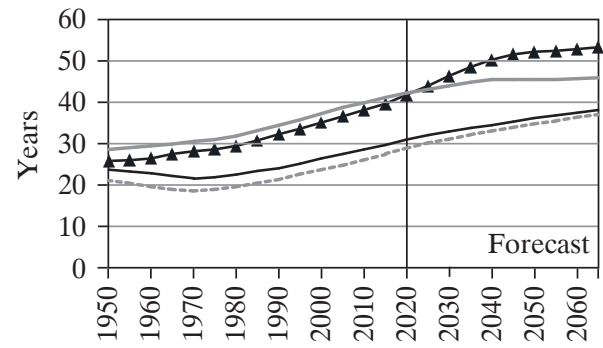

c) Age index

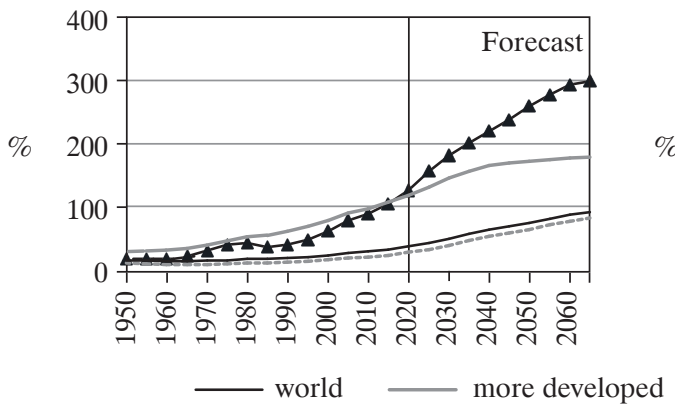

b) Age ratio

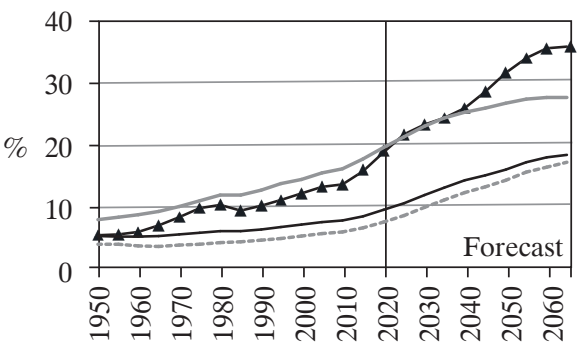

d) Old age dependency ratio

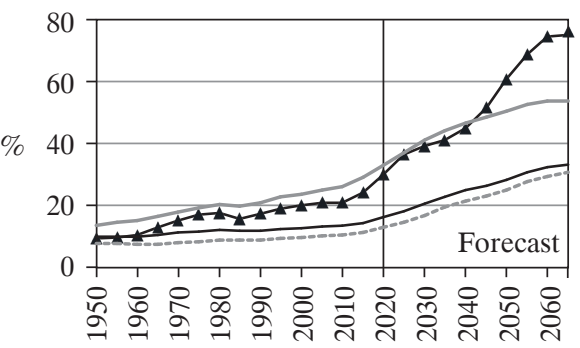

less developed $\longleftarrow$ Poland

Fig. 5. Selected Measures of Population Ageing in Poland Compared to the World and to Economic Regions, 1950-2065

Source: author's own elaboration based on United Nations (2018).

According to the forecast, in 2065 Poland will be among the top-ranking oldest countries in the world. Owing to the age median and the old age dependency ratio, it will be in fifth place in the ranking of the oldest 
populations, its age index will be the third highest in the world, while its age ratio will reach the sixth highest value globally (Figure 6).

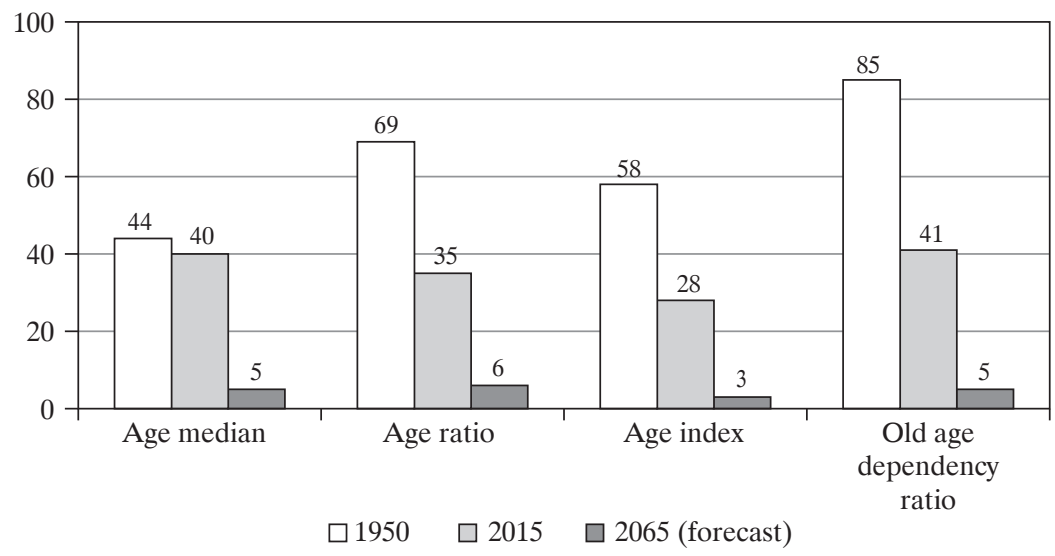

Fig. 6. Poland's Position in the Rankings of the Oldest Countries in the World in 1950, 2015, and 2065

Source: author's own elaboration based on United Nations (2018).

Table 3. Countries with the Highest Values of Measures of Population Ageing in 2065 (Forecast)

\begin{tabular}{|c|c|c|c|c|c|c|c|}
\hline \multicolumn{2}{|c|}{ Age median } & \multicolumn{2}{|c|}{ Age ratio } & \multicolumn{2}{|c|}{ Age index } & \multicolumn{2}{|c|}{$\begin{array}{l}\text { Old age dependency } \\
\text { ratio }\end{array}$} \\
\hline 1. Singapore & 54.7 & $\begin{array}{l}\text { 1. South } \\
\text { Korea }\end{array}$ & 37.7 & 1. Singapore & 343.5 & $\begin{array}{r}\text { 1. South } \\
\text { Korea }\end{array}$ & 82.9 \\
\hline 2. Portugal & 54.2 & 2. Taiwan & 37.6 & 2. Portugal & 308.7 & 2. Taiwan & 82.8 \\
\hline 3. Greece & 53.7 & 3. Singapore & 36.8 & 3. Poland & 299.2 & 3. Japan & 78.0 \\
\hline $\begin{array}{l}\text { 4. South } \\
\text { Korea }\end{array}$ & 53.5 & 4. Japan & 36.2 & $\begin{array}{l}\text { 4. South } \\
\text { Korea }\end{array}$ & 296.4 & 4. Singapore & 76.0 \\
\hline 5. Poland & 53.3 & 5. Portugal & 35.9 & 5. Greece & 296.1 & 5. Poland & 74.9 \\
\hline 6. Taiwan & 53.3 & 6. Poland & 35.8 & 6. Taiwan & 290.6 & 6. Portugal & 74.4 \\
\hline 7. Portorico & 53.1 & 7. Greece & 35.3 & 7. Japan & 283.1 & 7. Hong Kong & 73.5 \\
\hline 8. Japan & 52.8 & 8. Albania & 34.5 & 8. Portorico & 280.0 & 8. Greece & 72.9 \\
\hline 9. Spain & 52.3 & 9. Portorico & 34.4 & 9. Spain & 271.6 & 9. Albania & 72.5 \\
\hline $\begin{array}{l}\text { 10. Saint } \\
\text { Lucia }\end{array}$ & 52.1 & $\begin{array}{l}\text { 10. Hong } \\
\text { Kong }\end{array}$ & 34.3 & $\begin{array}{r}\text { 10. Saint } \\
\text { Lucia }\end{array}$ & 270.6 & 10. Portorico & 70.4 \\
\hline
\end{tabular}

Source: author's own elaboration based on United Nations (2018). 
In 2025 Poland's population will turn from old to very old (age ratio of over 20\%). In 2065 Poland will surpass most of the highly developed countries in the rankings of the oldest countries in the world, including European Union members, with the exception of Greece and Portugal. Poland will be the oldest country in the region of Central and Eastern Europe and the oldest among the new EU Member States (Table 3).

\section{Population Ageing and Poland's International Investment Position}

From the point of view of the impact on the IIP, the course of Poland's population ageing process in the years 1950-2065 may be symbolically divided into three periods. The first encompasses the years 1950-2000, during which Poland was a young country with a large proportion (over 30\%) of people of pre-working age, a low percentage of people of post-working age (less than 15\%), and a growing population (Figure 7).

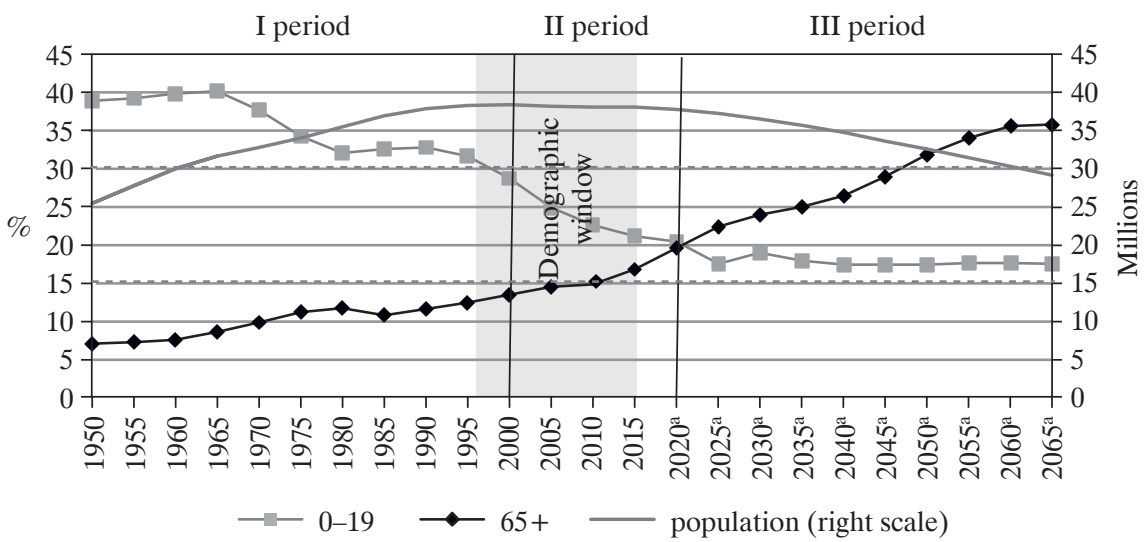

${ }^{\text {a }}$ Forecast

Fig. 7. Changes in the Percentage of People Aged 0-19 and 65+ and the Population of Poland, 1950-2065

Source: author's own elaboration based on United Nations (2018).

The second stage comprises the years 2000-2020, during which the percentage of people of pre-working age fell below $30 \%$ and showed a strong falling trend, the percentage of people aged $65+$ was at a relatively moderate level (12\%-18\%), and the population stabilised at approximately 38 million (Figure 7). Furthermore, the percentage of working people aged 45-64, i.e. "prime savers", rose significantly. In the years 2000-2015, for the first 
time in the post-war period, the share of prime savers in Poland was higher than the average for developed countries (Figure 8). Therefore, it may be concluded that in the period under discussion, in particular in the years 2000-2015, there was a demographic window in Poland, i.e. favourable demographic conditions, which create an opportunity for achieving economic benefits (a demographic dividend) - Figure 7.

The third period concerns the forecast for the demographic changes in 2020-2065, during which the expected rate of growth in the percentage of elderly people $(65+)$ will be significantly higher than the dynamics of the decrease in the young population (0-19). In 2020 the percentage of the post-working age group will become equal to the percentage of the pre-working age group and will be rising quickly, while the share of young people will stabilise at a level slightly above $16 \%$. Consequently, population ageing will determine the increase in the dependency ratio of people of non-working age from $61.4 \%$ in 2020 up to $109.2 \%$ in 2065 (Figure 9). Such rapid population ageing, resulting in a growing total demographic dependency ratio, will be accompanied by a significant drop in Poland's population from 37.9 million in 2020 to 28.7 million in 2065 (Figure 7). An additional, unfavourable phenomenon will be the dramatic decrease in the percentage of prime savers, which is forecast from 2040 onwards (Figure 8).

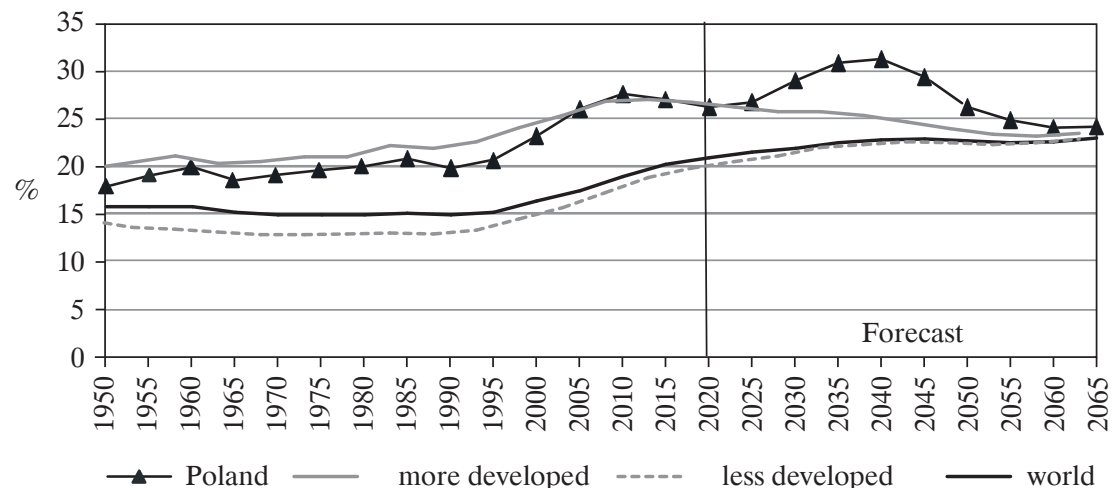

Fig. 8. Percentage of Prime Savers in the Population of Poland, Economic Regions, and the World, 1950-2065

Source: author's own elaboration based on United Nations (2018).

A comparison of the trend in the total demographic dependency ratio (as a synthetic measure of the economic effects of changes in population age structure) in Poland with the average for economic regions and for 
the world shows that Poland's demographic position in relation to other countries, particularly in relation to developed countries, may be considered as having been most favourable in the years 2000-2020 (the second period). The demographic dependency ratio of people of non-working age was lower than the global average, the average for developing countries and - for the first time in the post-war period - the ratio remained at a lower level than the average for developed countries (Figure 9). From 2020, as a result of an acceleration in the ageing process, the demographic dependency ratio in Poland will, however, display a constantly rising trend. Around 2045 a substantial deterioration in Poland's demographic position is expected the total demographic dependency ratio in Poland will exceed the average values of the measure for the world as a whole, for developing regions, and for developed countries (Figure 9).

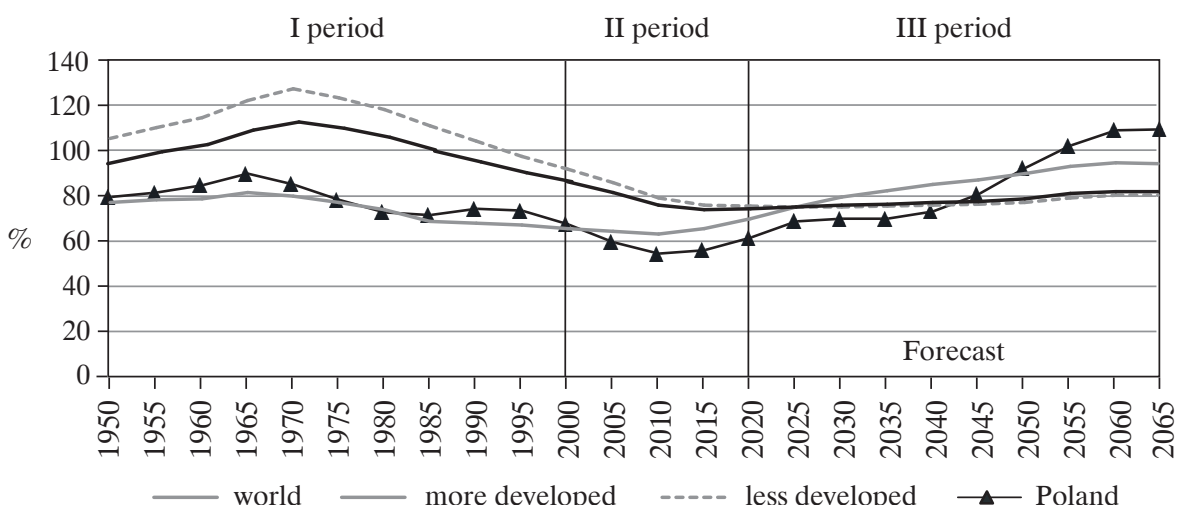

Fig. 9. Total Demographic Dependency Ratio in Poland Compared to the World Average and the Average for Economic Regions, 1950-2065

Source: author's own elaboration based on United Nations (2018).

According to the theory, in the first of the isolated periods, in the years 1950-2000, the relatively low progress of Polish population ageing was a factor behind the inflow of foreign capital from countries with older populations. A shortage of savings in relation to investment needs and an increased demand for external financing, which are characteristic to young societies, ought to result in a deterioration of / a negative NIIP. The specific conditions of the economic system in the first four decades of that period, including the lack of financial openness, modified the influence of demography and limited the influx of foreign capital (Figure 10). 


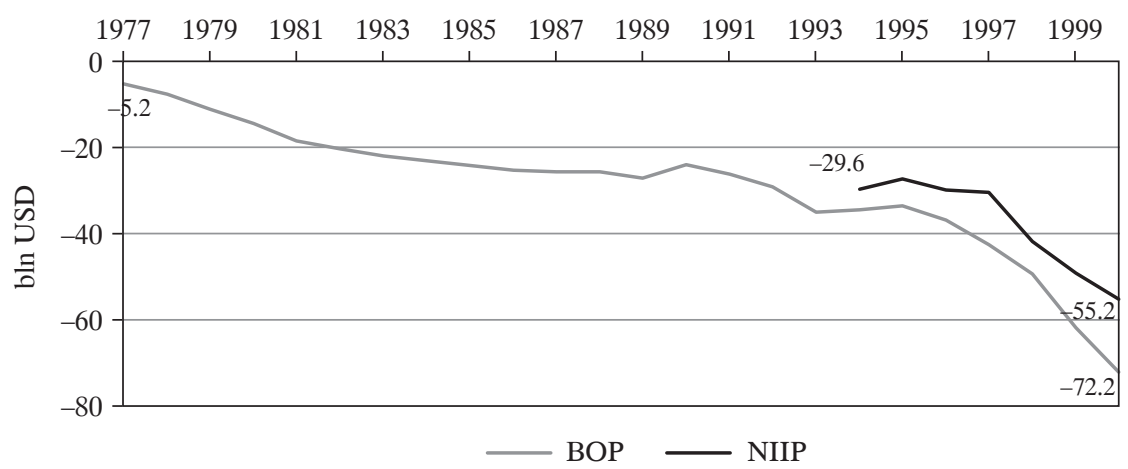

Note: Accumulated current account balance (BOP) as an approximation of NIIP value (data have been available since 1976). Data on Poland's NIIP have been available since 1994.

Fig. 10. Accumulated Current Account Balance (BOP) and Net IIP, 1977-2000 Source: author's own elaboration based on NBP (2018) and World Bank (2018).

In the 2000-2020 period, as a result of the ongoing ageing process, the population changed from a young one to an old one (with a relatively low demographic dependency ratio and a relatively high percentage of prime savers). The advancement and pace of population ageing should thus be conducive to the growth of national savings, import reduction, and an increase in capital exports to relatively younger countries. However, the political transformation, underdevelopment and the process of catching up to the EU-15, and the global economic and financial crisis offset the positive effects of demographic changes in the first decade of the period under discussion. Those changes might, however, have contributed to Poland's improved net international investment position recorded in the second half of that period (in the years 2014-2016) - Figure 11.

Despite the fact that after 2002 the relation of Poland's NIIP to its GDP significantly exceeded the value that the European Commission considered safe from the point of view of external balance evaluation (the so-called "EU threshold", cf. Figure 11), Poland's situation was seen as stable. This was determined by, inter alia, the structure of Poland's foreign liabilities, in which foreign direct investments were dominant (NBP 2016, pp. 20-21).

After 2040 it is likely that the accumulated effects of demographic changes will have a negative impact on the economy, involving: a reduction in labour resources, a decrease in efficiency, shrinkage of the market, a high burden on public finances (including pension payments, health care spending, long-term care, etc.), tax increases (resulting from growing 
budgetary expenditure and a decreasing tax base). If those threats transpire, it will additionally cause unfavourable changes (in terms of external balance) in the IIP structure. This will lead to a decrease in Poland's competitiveness and investment attractiveness, in particular for long-term capital, including foreign direct investment, for which Poland will compete with younger economies both in the majority of developed countries and in the dynamically growing, young markets of developing countries. Furthermore, the costs of attracting foreign capital will rise.
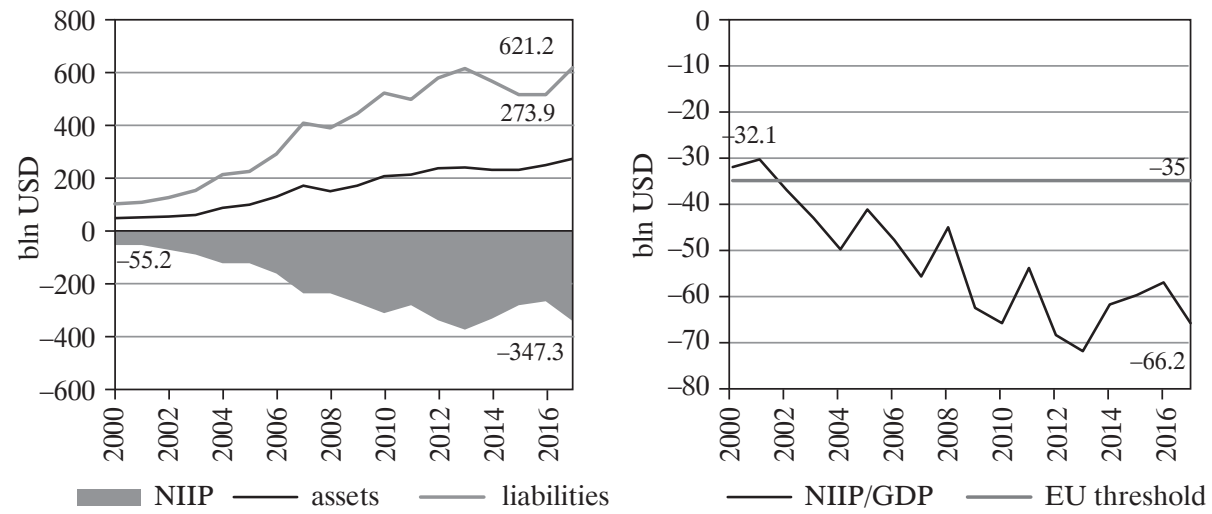

Fig. 11. Poland's International Investment Position, 2000-2017

Source: author's own elaboration based on NBP (2018) and World Bank (2018).

The progress of population ageing will contribute to an increased risk of the unproductive use of foreign capital (not on investment and development, but on financing the deficit in public finances generated by growing pension payments, etc.). Thus, a greater influx of foreign savings might not serve to maintain / increase the rate of growth and development but may cause foreign debt to grow, burdening the economy and making it dependent on external sources of financing. This raises the risk that after 2040 Poland may suffer economic stagnation, fall into "the medium income trap", and find it hard to catch up with other EU economies (Kalisz and Chrapek 2016, World Bank 2014). Therefore, the import of savings from abroad and high negative NIIP may change from a factor enabling / accelerating real convergence of the economy into a barrier to that process.

To conclude the discussion on the impact of population ageing on Poland's IIP, it needs to be stressed that savings and investments, and therefore the balance of capital flows and IIP, are affected by a series of 
other factors in addition to population ageing. Those factors modify the influence of population ageing, while some of them may weaken / offset its effects and others may strengthen them ${ }^{5}$.

\section{Conclusion}

After a period of youth in the years 1950-2000 and a mature stage in the years 2015-2020, in the next five decades Polish society will be one of the oldest populations in the world. The predicted progress of the population ageing process will be a factor in the growing demand for foreign capital and deterioration of Poland's international investment position.

The increased inflow of foreign capital from the "old" economy might not, however, translate into the expected maintenance of / increase in the rate of economic growth, while the substantial negative net international investment position may become a barrier to development in subsequent periods.

State policy will play an especially important role in alleviating the negative impact of population ageing on Poland's international investment position and its development opportunities in the coming decades. The priorities of that policy ought to focus on raising birth rates, raising the retirement age, increasing the professional activity of old-age pensioners and women, increasing the influx of migrants, limiting the budget deficit, and improving the net international investment position.

\section{Bibliography}

Ando, A. and Modigliani, F. (1963) "The 'Life-Cycle' Hypothesis of Saving: Aggregate Implications and Tests". American Economic Review 53(1), Part 1: 55-84.

Attanasio, O. and Violante, G. (2000) "The Demographic Transition in Closed and Open Economies: A Tale of Two Regions". IADB Working Paper 412.

Bańbuła, P. (2006) “Oszczędności i wybór międzyokresowy - podejście behawioralne”. Materialy $i$ Studia 208. Warszawa: NBP.

Bárány, Z., Coeurdacier, N. and Guibaud, S. (2016) "Fertility, Longevity, and Capital Flows". HIS Economics Series Working Paper 321. Vienna: Institute for Advanced Studies.

Börsch-Supan, A. (1992) "Saving and Consumption Patterns of the Elderly: The German Case". Journal of Population Economics 5(4): 289-303, https://doi.org/10.1007/ bf00163062.

\footnotetext{
${ }^{5}$ For reasons of limited space due to its extensive scope, this issue requires a separate study.
} 
Börsch-Supan, A. (2004) “Global Aging: Issues, Answers, More Questions”. Working Papers 084, University of Michigan.

Börsch-Supan, A., Ludwig, A. and Winter, J. (2001) "Aging and International Capital Flows". NBER Working Paper 8553. Cambridge: NBER, https://doi.org/10.3386/w8553.

Brooks, R. (2003) "Population Aging and Global Capital Flows in a Parallel Universe". IMF Staff Papers 50(2).

Bryant, R.C. (2006) "Asymmetric Demographic Transitions and North-South Capital Flows". Brookings Discussion Papers in International Economics 170.

Chawla, M. (2007) From Red to Gray: The Third Transition of Aging Populations in Eastern Europe and the Former Soviet Union. Washington: The World Bank.

Chinn, M. D. and Prasad, E. S. (2003) "Medium-term Determinants of Current Accounts in Industrial and Developing Countries: An Empirical Exploration". Journal of International Economics 59(1): 47-76.

Dekle, R. (2004) "Financing Consumption in an Aging Japan: The Roles of Foreign Capital Inflows and Immigration". NBER Working Paper 10781. Cambridge: NBER, https://doi.org/10.3386/w10781.

Domeij, D. and Floden, M. (2006) "Population Aging and International Capital Flows". International Economic Review 47(3): 1013-1032.

Gelinas, V. (2018) Currency Composition of Canada's International Investment Position, www.statcan.gc.ca (accessed: 2 July 2018).

Graff, M., Tang, K. K. and Zhang, J. (2012) "Does Demographic Change Affect the Current Account? A Reconsideration”. Global Economy Journal 12(4): 1-26, https:// doi.org/10.1515/1524-5861.1885.

Gudmundsson, G. S. and Zoega, G. (2014) "Age Structure and the Current Account". Economic Letters 123(2): 183-186, https://doi.org/10.1016/j.econlet.2014.02.001.

GUS (2018) Baza demograficzna, http://demografia.stat.gov.pl/bazademografia/ (accessed: 25 August 2018).

Hassan, A. F. M., Salim, R. and Bloch, H. (2011) "Population Age Structure, Saving, Capital Flows and the Real Exchange Rate: A Survey of the Literature". Journal of Economic Surveys 25(4): 708-736, https://doi.org/10.1111/j.1467-6419.2010.00665.x.

Hassan, K., Salim, R. and Bloch, H. (2015) "Demographic Transition and the Real Exchange Rate in Australia: An Empirical Investigation". New Zealand Economic Papers 49(1), https://doi.org/10.1080/00779954.2013.851016.

Higgins, M. (1998) "Demography, National Savings, and International Capital Flows". International Economic Review 39(2): 343-369, https://doi.org/10.2307/2527297.

IMF (2009) Balance of Payments and International Investment Position Manual. Sixth Edition (BPM6). Washington: IMF.

Kalisz, P. and Chrapek, C. (2016) Raport specjalny: Ostatnie spowolnienie to dopiero poczatek, www.citibank.pl/poland/homepage/polish/files2/komentarz20160909.pdf (accessed: 8 July 2018).

Lane, P. R. and Milesi-Ferretti, G. (2001) "Long-term Capital Movements". NBER Working Paper 8366. Cambridge: NBER, https://doi.org/10.3386/w8366.

Lührmann, M. (2003) "Demographic Change, Foresight and International Capital Flows". MEA Discussion Paper Series 03038.

Lv, J. X. (2018) "Population Age Structure, Urbanization and Real Exchange Rate: An Empirical Study Based on G20's Panel Data”. Modern Economy 9(02): 302-317, https://doi.org/10.4236/me.2018.92020. 
Mérette, M. and Georges, P. (2009) "Demographic Changes and the Gains from Globalisation: An Overlapping Generations CGE Analysis”. Working Papers 0903E. University of Ottawa.

Modigliani, F. and Brumberg, R. (1954) "Utility Analysis and the Consumption Function: An Interpretation of Cross-Section Data" in K. K. Kurihara (ed.) Post-Keynesian Economics. New Brunswick: Rutgers University Press.

NBP (2018) Statystyka bilansu ptatniczego, http://www.nbp.pl/home.aspx?f=/statystyka/ bilans_platniczy.html (accessed: 25 September 2018).

Okólski, M. and Fihel, A. (2012) Demografia. Wspótczesne zjawiska i teorie. Warszawa: Wydawnictwo Naukowe Scholar.

United Nations (2004) World Population to 2300. New York: United Nation.

United Nations (2005) World Population Prospects. The 2004 Revision, http://www.un. org/esa/population/publications/WPP2004/2004Highlights_finalrevised.pdf (accessed: 26 August 2018).

United Nations (2018) World Population Prospects 2017, https://esa.un.org/unpd/wpp/ Download/ Standard/Population/ (accessed: 26 August 2018).

World Bank (2014) Poland: Saving for Growth and Prosperous Aging. Washington: The World Bank.

World Bank (2016) Global Monitoring Report 2015/2016: Development Goals in an Era of Demographic Change. Washington: The World Bank.

World Bank (2018) DataBank, http://databank.worldbank.org/data/reports.aspx?Source =world development-indicators (accessed: 26 September 2018).

\section{Abstract}

\section{Starzenie się ludności a międzynarodowa pozycja inwestycyjna Polski}

Celem artykułu jest próba oceny wpływu starzenia się ludności na międzynarodową pozycję inwestycyjną Polski w najbliższym pięćdziesięcioleciu. Dla realizacji celu przeprowadzono badania literaturowe, analizę porównawczą mierników starzenia się populacji Polski i innych krajów oraz logiczne wnioskowanie. Wyniki badań wskazują, że prognozowany wysoki poziom zaawansowania procesu starzenia się ludności Polski w okresie 2020-2065 skutkować będzie wzrostem zapotrzebowania na zagraniczny kapitał, zwiększeniem ujemnej międzynarodowej pozycji inwestycyjnej netto i niekorzystnymi zmianami w strukturze zagranicznych pasywów. Napływ zagranicznego kapitału, indukowany starzeniem się populacji, może nie przełożyć się na oczekiwane utrzymanie lub zwiększenie tempa wzrostu gospodarczego, a duża ujemna międzynarodowa pozycja inwestycyjna netto może stać się barierą rozwoju w kolejnych okresach.

Słowa kluczowe: starzenie się ludności, międzynarodowe przepływy kapitału, międzynarodowa pozycja inwestycyjna, Polska. 